PERM JOURNAL OF PETROLEUM AND MINING ENGINEERING ВЕСТНИК ПНИПУ. ГЕОЛОГИЯ. НЕФТЕТАЗОВОЕ И ГОРНОЕ ДЕЛО ISSN 2224-9923 Volume/Tom 19 №3 2019

http://vestnik,pstu.ru/geo/

UDC 622.276.63

Article / Статья

(C) PNRPU / ПНИПУ, 2019

\title{
CHANGES IN THE PROPERTIES OF FLUIDS AND CHEMICAL REACTIONS PRODUCTS CAUSED BY ACID TREATMENT OF CARBONATE RESERVOIRS
}

\section{R.A. Khuzin, T.S. Yushchenko', G.P. Khizhniak²}

Gazpromneft Badra B.V., Iraq, (335 Royal Tulip Al-Rashid Hotel, Baghdad, 8070, Republic of Iraq)

${ }^{1}$ LLC ENERGOAVTOMATIKA (9 Chuksin deadlock, Moscow, 127206, Russia)

${ }^{2}$ Perm National Research Polytechnic University (29 Komsomolskiy av., Perm, 614990, Russian Federation)

\section{ИЗМЕНЕНИЕ СВОЙСТВ ФЛЮИДОВ И ПРОДУКТОВ ХИМИЧЕСКИХ РЕАКЦИЙ ПРИ СОЛЯНОКИСЛОТНЫХ ОБРАБОТКАХ КАРБОНАТНЫХ КОЛЛЕКТОРОВ}

\section{Р.А. Хузин, Т.С. Ющенко ${ }^{1}$, Г.П. Хижняк ${ }^{2}$}

Газпромнефть Бадра Б.В. (8070, Ирак, г. Багдад, Ройял Тьюлип Аль-Рашид Хоутел, оф. 335)

${ }^{1} \mathrm{OOO} \mathrm{«Энергоавтоматика»} \mathrm{(127206,} \mathrm{Россия,} \mathrm{г.} \mathrm{Москва,} \mathrm{Чуксин} \mathrm{тупик,} \mathrm{9)}$

${ }^{2}$ Пермский национальный исследовательский политехнический университет (614990, Россия, г. Пермь, Комсомольский проспект, 29) Received / Получена: 04.06.2019. Accepted / Принята: 01.08.2019. Published / Опубликована: 27.09.2019

Keywords:

carbonates, limestone, dolomite, acid treatment, diverter, viscosity, density, volume ratio, chemical reaction, reaction products, hydrochloric acid, phase state, calcium chloride, magnesium chloride, carbon dioxide, nitrogen, solubility, supercritical fluid, pressure, temperature, reaction time, reaction rate, core, neutralization, dissolving ability, Badra, Iraq.
Ключевые слова:

карбонаты, известняк, доломит, солянокислотная обработка, потокоотклонитель, вязкость, плотность, объемный коэффициент, химическая реакция, продукты реакции, соляная кислота, фазовое состояние, хлорид кальция, хлорид магния, углекислый газ, азот, растворимость сверхкритичный флюид, давление, температура, время реакции, скорость реакции, керн, нейтрализация, растворяющая способность, Бадра, Ирак
Acid treatment is one of the main methods of stimulating the near wellbore area of the wells opening the carbonate reservoirs.

Despite the extensive experience of using this technology both in Russia and abroad, as well as a significant number of studies, the success rate is hardly ever estimated at over $30 \%$

One of the reasons for the low success rate is neglect to the changes in the physical properties of fluids during injection, interaction with the rock and the properties of the reaction products in the wellbore and the near wellbore area during the acid treatment planning.

This paper discusses the main chemical reactions occurring during the interaction of hydrochloric acid with limestones and dolomites. The quantities of the substances resulting from a chemical reaction between $15 \%$ aqueous solution of acid and the carbonates have been determined. The properties (phase state, solubility, dependences of viscosity and density on pressure and temperature) of water, carbon dioxide, nitrogen, $15 \%$ aqueous solution of acid, solutions of calcium and magnesium chloride salts in the range of possible pressures and temperatures during the acid treatment were evaluated.

Due to the diversity of additives used in acid solutions, the paper proves the necessity of conducting laboratory experiments to evaluate their properties under the conditions expected during the acid stimulation.

Based on laboratory studies, the reaction time of $15 \%$ solution of hydrochloric acid with calcium carbonate was estimated The impact of the chemical diverter used for primary treatments at the Badra oilfield (Iraq) on the properties of the acid solution and the reaction time was determined. The changes in the solution viscosity depending on the acid temperature and concentration were determined.

The results provided in the work were used for the purposes of forecasting and evaluating the efficiency of acid treatment performed on the wells of the Badra oilfield.

Солянокислотная обработка (СКО) является одним из основных методов воздействия на призабойную зону скважин, вскрывающих карбонатные коллекторы.

Несмотря на огромный опыт их применения как в России, так и за рубежом и значительное количество выполненных исследований, успешность их проведения, по различным оценкам, не превышает $30 \%$.

Одной из причин низкой успешности является недостаточное внимание изменению физических свойств флюидов в процессе их закачки, взаимодействия с породой и свойств получаемых продуктов реакции в условиях ствола скважины и призабойной зоны пласта при проектировании СКО.

Рассмотрены основные химические реакции, протекаюшие при взаимодействии соляной кислоты с известняками и доломитами. Определены количества образующихся веществ при взаимодействии $15 \%$-ного водного раствора соляной кислоты с карбонатами. Оценены свойства (фазовое состояние, коэффициент растворимости, зависимости вязкости и плотности от давления и температуры) воды, углекислого газа, азота, 15\%-ного водного раствора соляной кислоты, растворов солей хлорида кальция и магния в диапазоне возможных при СКО давлений и температур.

Из-за разнообразия используемых для растворов кислот добавок показана необходимость проведения лабораторных экспериментов для оценки их свойств в ожидаемых при кислотной стимуляции условиях.

На основе лабораторных исследований выполнена оценка времени реакции $15 \%$-ного раствора соляной кислоты с карбонатом кальция. Определено влияние химического потокоотклонителя, применяемого при первичных обработках на месторождении Бадра (Ирак), на свойства кислотного раствора и времени реакции. Определены изменения вязкости раствора в зависимости от температуры и концентрации кислоты.

Приведенные в работе результаты использованы при проектировании и оценке эффективности СКО скважин месторождения Бадра

Rinat A. Khuzin (Author ID in Scopus: 57205219438) - Head of Development Department (tel.: +007 96866214 56, e-mail: Khuzin.ra@gazpromneft-badra.com) Taras S. Yushchenko (Author ID in Scopus: 57210418887) - PhD in Physical and Mathematical Sciences, Chief Engineer of the Project (tel.: +007 969 114 7997, e-mail: yushchenko@phystech.edu).

Grigoriy P. Khizhnyak (Author ID in Scopus: 36711848000) - Doctor of Engineering, Associate Professor at the Department of Oil and Gas Technologies (tel.: +007 342 219 82 92, e-mail: xgp@mail.ru). The contact person for correspondence.

Хузин Ринат Альвертович - начальник управления разработки (тел.: +007 96866214 56, e-mail: Khuzin.ra@gazpromneft-badra.com) Юшенко Тарас Сергеевич - кандидат физико-математических наук, главный инженер проекта (тел. +007 969 114 79 97, e-mail: yushchenko@phystech.edu). Хижняк Григорий Петрович - доктор технических наук, доцент, заведующий кафедрой нефтегазовых технологий (тел.: +007 3422198292 , e-таil: хgр@pstu.ru). Контактное лицо для переписки. 


\section{Introduction}

According to different estimates, up to $50-60 \%$ of the current world oil reserves and significantly more gas reserves are contained in the reservoirs formed by carbonate rocks [1-3]. In the process of reservoir penetration and well perforation, workovers and operation, the flow properties of the near wellbore formation may deteriorate, reducing the productivity of the wells.

The main method of recovery and improvement of the hydrodynamic connection between the well and the formation in the carbonate collectors involves the introduction of acid compositions to dissolve foreign clogging materials that get into the formation and/or the rock itself, creating highly permeable channels referred to as "wormholes".

In the foreign studies, the acid treatment of a well was first mentioned in 1895 [4, 5], and in Russian literature, the first mentioning dates back to $1934[6,7]$. Despite its long-standing history and the huge scope of the conducted research and universal application (the number of acid treatments in the world exceeds 40 thousand operations per year [5]), its success rate is hardly estimated as exceeding 30\% [8-10].

One of the reasons for the low success rate of acid treatment is insufficient attention to the planning stage. Today, a significant part of the treatment operations is based on nothing but the previous experience and the so-called rule of thumb [5].

To improve the method efficiency, much attention has been paid lately to simulation at the acid treatment planning stage [11-16]. An important component of modelling the wellbore and the near wellbore processes is the evaluation of the changes that occur in the properties of the fluids used for acid treatment and the chemical reaction products under the influence of pressure and temperature, as well as the evaluation of the impact made by the acid treatment additives on both the fluid properties and the time of reaction between the used compositions and the rock-forming minerals.

For this reason, the paper studies the principal chemical reactions occurring during the interaction of the acid with the carbonates, and evaluates the amounts of the reaction products.

Based on the generalization of the data provided in different published researches, the physical properties of the fluids used for the acid treatment and the products of the chemical reactions are analysed in a broad range of pressures and temperatures that occur in the well and the near wellbore area during the well stimulation. The key factors that influence their physical properties are identified. The dependencies of their fluids on the pressure and temperature are established.

Besides, based on the laboratory research, the impact of the diverter used for primary treatment at the Badra oilfield (Iraq) on the changing acid solution properties under the influence of temperature and acid concentration is assessed, and its impact on the speed of reaction between the acid composition and calcium carbonate is evaluated.

\section{Physical and chemical aspects of acids interaction with carbonate reservoirs}

Carbonate rocks are sedimentary formations, consisting of carbonate minerals by $50 \%$ or more [17]. The main rock-forming minerals are calcite $\left(\mathrm{CaCO}_{3}\right)$, dolomite $\left(\mathrm{CaMg}\left(\mathrm{CO}_{3}\right)_{2}\right)$, and the combinations thereof.

The reaction of hydrochloric acid with limestone and dolomite is described in the following equations:

$$
\begin{gathered}
2 \mathrm{HCl}+\mathrm{CaCO}_{3}=\mathrm{H}_{2} \mathrm{O}+\mathrm{CO}_{2}+\mathrm{CaCl}_{2}, \\
4 \mathrm{HCl}+\mathrm{CaMg}\left(\mathrm{CO}_{3}\right)_{2}= \\
=2 \mathrm{H}_{2} \mathrm{O}+2 \mathrm{CO}_{2}+\mathrm{CaCl}_{2}+\mathrm{MgCl}_{2} .
\end{gathered}
$$

These equations can be used for calculation of the weight of rock dissolved in one weight unit of acid for a complete reaction:

$$
\begin{aligned}
\beta_{\mathrm{CaCO}_{3}} & =\frac{M_{\mathrm{CaCO}_{3}} \cdot 1}{M_{\mathrm{HCl}} \cdot 2}=\frac{100,09 \cdot 1}{36,46 \cdot 2}=1,373 \mathrm{~kg}, \\
\beta_{\mathrm{CaMg}\left(\mathrm{CO}_{3}\right)_{2}} & =\frac{M_{\mathrm{CaMg}\left(\mathrm{CO}_{3}\right)_{2}} \cdot 1}{M_{\mathrm{HCl}} \cdot 4}=\frac{184,4 \cdot 1}{36,46 \cdot 4}=1,264 \mathrm{~kg},
\end{aligned}
$$

where $M$ is the molar mass of the substance, $\mathrm{g} /$ mole.

For the treatment of carbonate reservoirs, $15 \%$ solution of acid $(\mathrm{HCl})$ is usually used.

To proceed to the volume measurement units with the weight concentration of acid in the solution in mind, the following formula is used:

$$
X_{C}=\frac{\rho_{\mathrm{HCl}}}{\rho_{\text {rock }}} \beta_{\text {rock }} \cdot C,
$$

where $\rho_{\text {rock }}, \rho_{\mathrm{HCl}}$ are the density of the rock and acid, $\mathrm{kg} / \mathrm{m}^{3} ; \beta_{\text {rock }}$ is the ratio of rock solubility in $100 \%$ acid solution; and $C$ is the weight concentration of acid, $\%$. 
In the complete reaction between the rock and the acid, assuming the density of limestone to be $2710 \mathrm{~kg} / \mathrm{m}^{3}$, the density of dolomite to be to $2870 \mathrm{~kg} / \mathrm{m}^{3}$, and that of the $15 \% \mathrm{HCl}$ solution at $20^{\circ} \mathrm{C}$ to be $1073 \mathrm{~kg} / \mathrm{m}^{3}$, the solubility will amount to as follows:

- limestone $X_{15 \%}=0.082 \mathrm{~m}^{3} / \mathrm{m}^{3}$;

- dolomite $X_{15 \%}=0.071 \mathrm{~m}^{3} / \mathrm{m}^{3}$.

Table 1 presents the solubility values of the carbonate minerals depending on the hydrochloric acid concentration [18].

With that being said, the volumes of the reacting substances and the resulting products can be calculated. The results are provided in Table 2 .

\section{Physical properties of the injected fluids and chemical reaction products at different temperatures and pressures}

The physical properties of the solutions and products of their reactions depend on the pressure and temperature, which can vary in a broad range and depend on the surface conditions, depth of the formation, geothermal gradient, field development system, well operating conditions etc. As a rule, the increase in depth causes a simultaneous increase in both pressure and temperature values. Though the reaction of $\mathrm{HCl}$ with carbonates is exothermic, the heat emitted during the contact with the environment disperses quickly [1]. Besides, acid treatment often

Table 1

Mineral solubility under different concentrations of acid

\begin{tabular}{|l|c|c|c|c|c|}
\hline \multirow{2}{*}{ Mineral } & \multicolumn{5}{|c|}{ Acid concentration, \% } \\
\cline { 2 - 6 } & 100 & 5 & 10 & 15 & 30 \\
\hline $\mathrm{CaCO}_{3}$ & 1.370 & 0.026 & 0.053 & 0.082 & 0.175 \\
\hline $\mathrm{CaMg}\left(\mathrm{CO}_{3}\right)_{2}$ & 1.270 & 0.023 & 0.046 & 0.071 & 0.152 \\
\hline
\end{tabular}

Table 2

Volumes of the reacting substances and reaction products, $\mathrm{m}^{3}$, under standard conditions

$$
\left(t=20{ }^{\circ} \mathrm{C}, P=0.1 \mathrm{MPa}\right)
$$

\begin{tabular}{|l|c|c|c|c|c|c|}
\hline \multicolumn{1}{|c|}{ Mineral } & $\begin{array}{c}\text { Mineral } \\
\text { volume }\end{array}$ & $\begin{array}{c}15 \% \\
\mathrm{HCl}\end{array}$ & $\mathrm{H}_{2} \mathrm{O}^{*}$ & $\mathrm{CO}_{2}$ & $\mathrm{CaCl}_{2}$ & $\mathrm{MgCl}_{2}$ \\
\hline $\mathrm{CaCO}_{3}$ & 0.082 & 1 & 0.952 & 52.822 & 0.114 & - \\
\hline $\mathrm{CaMg}\left(\mathrm{CO}_{3}\right)_{2}$ & 0.071 & 1 & 0.952 & 52.822 & 0.057 & 0.045 \\
\hline
\end{tabular}

Note: $*$ - the volume of water used for assessment includes the volume contained in the $15 \% \mathrm{HCl}$ solution and the volume produced in the reaction. uses nitrogen injection $\left(\mathrm{N}_{2}\right)$ to reduce the solution density, which means that its properties should also be described.

The considered range of possible pressures and temperatures is provided in Table 3 and covers the majority of possible values that occur during acid treatment.

$\mathrm{CaCO}_{3}$ and $\mathrm{CaMg}\left(\mathrm{CO}_{3}\right)_{2}$ are solid substances at any temperature and pressure and have the densities of 2710 and $2870 \mathrm{~kg} / \mathrm{m}^{3}$ respectively. As their proportions in the rock may vary, the average density remains within the said range.

$\mathbf{H}_{2} \mathbf{O}$ is the main component of the acid solution and the resulting saline solutions. That is why their properties depend on the properties of the water to such a great extent.

Under standard conditions, water is a liquid with the density of $1000 \mathrm{~kg} / \mathrm{m}^{3}$ and the viscosity of 1 $\mathrm{mPa} \cdot \mathrm{sec}$.

The water phase state diagram is schematically shown in Fig. 1.

Table 3

Range of pressures and temperatures possible during the acid treatment

\begin{tabular}{|l|c|c|c|c|c|}
\hline \multirow{2}{*}{ Substance } & \multirow{2}{*}{ Conditions } & \multicolumn{2}{c|}{ Temperature, ${ }^{\circ} \mathrm{C}$} & \multicolumn{2}{c|}{ Pressure, MPa } \\
\cline { 3 - 6 } & & $\begin{array}{c}\text { mini- } \\
\text { mum }\end{array}$ & $\begin{array}{c}\text { maxi- } \\
\text { mum }\end{array}$ & $\begin{array}{c}\text { mini- } \\
\text { mum }\end{array}$ & $\begin{array}{c}\text { maxi- } \\
\text { mum }\end{array}$ \\
\hline $\begin{array}{l}\mathrm{CaCO}_{3} \\
\text { and } \mathrm{CaMg}\left(\mathrm{CO}_{3}\right)_{2}\end{array}$ & Formation & 30 & 250 & 3 & 100 \\
\hline $\begin{array}{l}15 \% \text { aqueous } \\
\text { solution of } \mathrm{HCl}\end{array}$ & $\begin{array}{c}\text { Well + } \\
\text { formation }\end{array}$ & 20 & 250 & 0.1 & 100 \\
\hline $\mathrm{H}_{2} \mathrm{O}$ & $\begin{array}{c}\text { Well + } \\
\text { formation }\end{array}$ & 20 & 250 & 0.1 & 100 \\
\hline $\mathrm{CO}_{2}$ & Formation & 30 & 250 & 3 & 100 \\
\hline $\begin{array}{l}\mathrm{Aqueous} \mathrm{solution} \\
\text { of } \mathrm{HCl}\end{array}$ & Formation & 30 & 250 & 3 & 100 \\
\hline $\begin{array}{l}\mathrm{Aqueous} \mathrm{solution} \\
\text { of } \mathrm{CaCl}\end{array}+\mathrm{MgCl}_{2}$ & Formation & 30 & 250 & 3 & 100 \\
\hline $\mathrm{N}_{2}$ & $\begin{array}{c}\text { Well + } \\
\text { formation }\end{array}$ & 20 & 250 & 0.1 & 100 \\
\hline
\end{tabular}

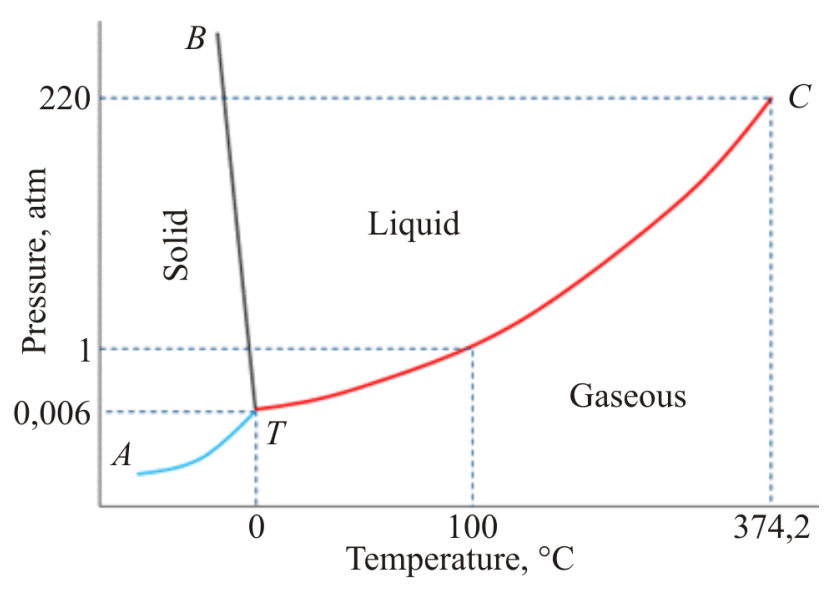

Fig. 1. Diagram of Phase State of the Water 


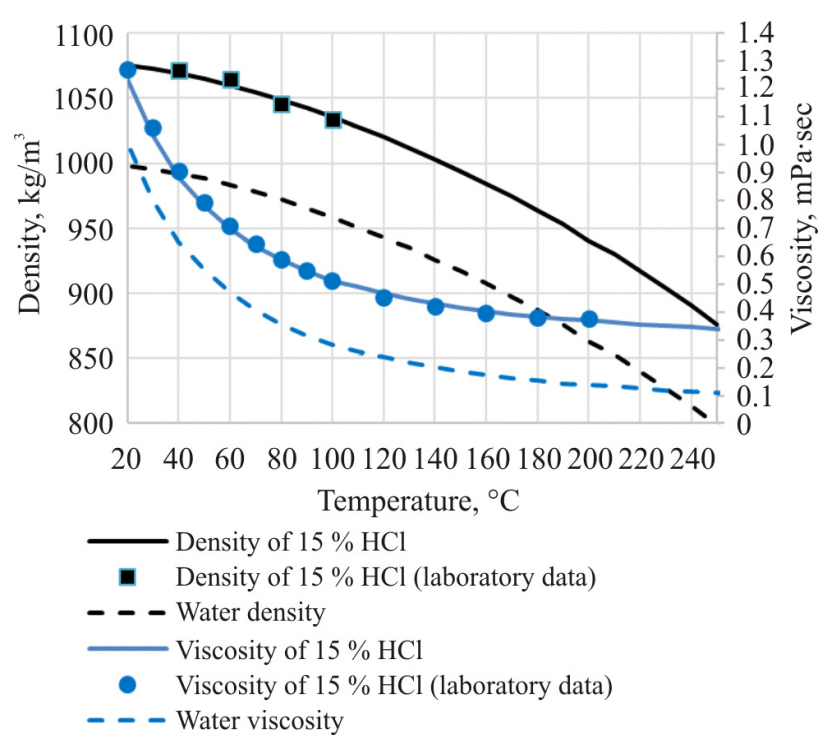

Fig. 2. Dependence of water density and viscosity on temperature for the $T C$ saturation line and $15 \%$ aqueous solution of $\mathrm{HCl}$

The curves in Fig. 1 show the conditions, in which the phases are balanced. The $B T$ curve characterizes the ice melting pressure and temperature. The $T C$ curve characterizes the pressure and temperature of the water transition into the gaseous state. Point $C$ is called the critical point (for water $T_{\mathrm{cr}}=374.2{ }^{\circ} \mathrm{C}$ and for $P_{\mathrm{cr}}=218.3 \mathrm{~atm}$ [19]). When pressure and temperature values exceed this point, the gas (steam) and liquid phases of water are impossible to recognize (supercritical fluid).

For the considered pressure and temperature values, water is obvious to remain in the liquid phase.

The results of measuring water viscosity depending on the pressure and temperature are provided in $[19,20]$. The main influence on water viscosity is rendered by temperature: as the temperature rises, the water viscosity declines. Pressure increase causes an insignificant increase in the water viscosity and may be neglected in practical calculations.

The dependence of water viscosity on the $T C$ saturation line is provided in [20] and shown in Fig. 2.

Water density depends on pressure and temperature. As the temperature rises, the water density declines, and if grows as the pressure increases. Water belongs to weakly compressible fluids, with the dependence of density change on the pressure presented as follows [21]

$$
\rho(P, T)=\rho_{0}\left(P_{0}, T\right)\left[1+c_{w}\left(P-P_{0}\right)\right],
$$

where $\rho(P, T)$ is the density at pressure $P$ and temperature $T ; \rho_{0}\left(P_{0}, T\right)$ is the density at known pressure $P_{0}$ and temperature $T ; c_{w}$ is the compression ratio. This formula can be used for the fluid compression within the range of $10^{-5}-10^{-6} \mathrm{~atm}^{-1}$ [22]. For pure water, compressibility at $20^{\circ} \mathrm{C}$ equals to $0.5 \cdot 10^{-5} \mathrm{~atm}^{-1}[23]$.

The formation volume factor at a given pressure and temperature is determined according to the following formula [22]

$$
B(P, T)=\frac{V(P, T)}{V\left(P_{0}, T_{0}\right)}=\frac{\rho_{0}\left(P_{0}, T_{0}\right)}{\rho(P, T)},
$$

where $\rho_{0}\left(P_{0}, T_{0}\right)$ is the fluid density at the standard terms of $P_{0}=1 \mathrm{~atm}, T_{0}=20{ }^{\circ} \mathrm{C} ; \rho(P, T)$ is the fluid density at the given conditions of $P$ and $T$.

As a rule, the pressure-determined density change is taken into account for hydrodynamic modelling because the huge injected and edge water volumes make a significant impact on the final results. In the acid treatment process, the volume of the injected aqueous solutions does not exceed several hundred cubic meters and the pressure-caused density changed can be neglected by regarding the solutions as incompressible.

The dependence of water density on temperature is more significant [20] and for the saturation line it is provided in Fig 2.

Under standard conditions, $15 \%$ aqueous solution of $\mathrm{HCl}$ is a liquid with the density of $1073 \mathrm{~kg} / \mathrm{m}^{3}$ and the viscosity of $1.26 \mathrm{mPa} \cdot \sec [24,25]$.

Based on the fact that the acid solution contains $85 \%$ of water, its freezing and boiling temperatures are 27.6 and $+108^{\circ} \mathrm{C}$ respectively [26], and the liquid phase area of the solution is broader than that of water. Consequently, within the considered pressure and temperature range the solution remains in the liquid phase.

For the calculations, the pressure-caused change of density and viscosity of the $15 \%$ aqueous solution of $\mathrm{HCl}$ can also be neglected similarly as for water.

The change of $\mathrm{HCl}$ concentration increases the viscosity and density of the solution [25, 27].

The change of viscosity of $15 \% \mathrm{HCl}$ solution depending on the temperature for the interval from 20 to $200{ }^{\circ} \mathrm{C}$ is provided in paper [1] and shown in Fig. 2. For higher temperatures, the solution viscosity can be estimated with the accuracy sufficient for practical calculations by extrapolating the data with 
due regard to the dependence of water viscosity on the temperature.

Laboratory data about the density of $15 \% \mathrm{HCl}$ solution up to the temperature of $100^{\circ} \mathrm{C}$ [24], as well as dependencies for higher temperatures estimated by means of extrapolation with due regard to the water data, are provided in Fig. 2.

\section{Water solutions of salts $\mathrm{MgCl}_{\mathbf{2}}$ and $\mathrm{CaCl}_{\mathbf{2}}$}

Considering the density of calcium chloride as equal to $2150 \mathrm{~kg} / \mathrm{m}^{3}$ and the volume of salt and water produced in the reaction with calcium carbonate, its mass concentration in water equals to $20,5 \%$. Whereas the solubility of calcium chloride in water at $20^{\circ} \mathrm{C}$ equals to $74.5 \mathrm{~g}$ in $100 \mathrm{~g}$ of water and increases with the temperature [24], the calcium chloride produced in the reaction is fully dissolved in the water at any temperature.

In the reaction with dolomite, the mass concentrations of calcium chloride and magnesium chloride (with the density of $2320 \mathrm{~kg} / \mathrm{m}^{3}$ ) amount to 12.87 and $11.04 \mathrm{~g}$ per $100 \mathrm{~g}$ of water, with the total mass concentration amounting to $19.3 \%$. Taking into account that the solubility of these salts in water at $20^{\circ} \mathrm{C}$ amounts to $74 ю 5$ and $52 \% 8 \mathrm{~g}$ per $100 \mathrm{~g}$ of water and increases with the temperature [24], potassium chloride and magnesium chloride produced in the reaction are fully dissolved in the water at any temperature.

The solution produced in the chemical reaction between the acid and the rock may remain liquid at the temperatures significantly below $0^{\circ} \mathrm{C}$ [28], depending on the concentration. This means that for them the $B T$ line in the water phase state diagram (see Fig. 1) shifts to the left.

The boiling temperature of the solutions is higher than that of water and increases with concentration [29], shifting the TC line (see Fig. 1) to the right. Thus, in the given conditions the solutions of these salts will remain in the liquid phase.

The viscosity of aqueous solutions depends on pressure, temperature, quantity and type of the dissolved salts. The viscosity rises as the pressure and salinity increase and the temperature declines. The existence of dissolved gas makes a little influence on the water solution viscosity [30] and may be neglected in practical calculations.

The density $\rho, \mathrm{kg} / \mathrm{m}^{3}$, and dynamic viscosity $\mu$, $\mathrm{Pa} \cdot \mathrm{sec}$, of the water solution of $\mathrm{CaCl}_{2}$ and $\mathrm{MgCl}_{2}$ with the weight content of the dissolved component $w, \mathrm{~kg} / \mathrm{kg}$, at the temperature $t,{ }^{\circ} \mathrm{C}$, can be taken from the manuals [24] or calculated with to the relational equations [29]

$$
\begin{aligned}
& \rho=\rho_{\mathrm{B}} \exp \left[w\left(a_{1}+a_{2} 10^{-4} t-a_{3} 10^{-6} t^{2}\right)\right], \\
& \mu=\mu_{\mathrm{B}} \exp \left[w\left(b_{1}+b_{2} 10^{-2} t-b_{3} 10^{-7} t^{2}\right)\right],
\end{aligned}
$$

where $\rho_{\mathrm{w}}$ is water density at the given temperature, $\mathrm{kg} / \mathrm{m}^{3} ; \quad \mu_{\mathrm{w}}$ is water viscosity at the given temperature, $\mathrm{Pa} \cdot \mathrm{sec} ; w$ is mass concentration of salt in the water, fraction of a unit; $a_{i}$ and $b_{i}$ are the ratios set out in Table 4.

Table 4

Empirical ratios for determining the density and viscosity of aqueous saline solution

\begin{tabular}{|l|c|c|c|c|c|c|}
\hline Substance & $a_{1}$ & $a_{2}$ & $a_{3}$ & $b_{1}$ & $b_{2}$ & $b_{3}$ \\
\hline $\mathrm{CaCl}_{2}$ & 0.8101 & 10.673 & 6.224 & 3.4143 & -0.3062 & 84.004 \\
\hline $\mathrm{MgCl}_{2}$ & 0.7764 & 18.216 & 7.466 & 5.0164 & -0.8807 & -96.036 \\
\hline $\mathrm{NaCl}$ & 0.6653 & 14.146 & 10.308 & 2.0544 & 0.4135 & 1.047 \\
\hline
\end{tabular}

In a reaction with a combined type of carbonates, the solution property can be determined with the additivity principle [31]. For the aqueous solutions of $\mathrm{CaCl}_{2}$ and $\mathrm{MgCl}_{2}$, the equation looks as follows:

$$
\begin{aligned}
\rho= & \rho_{\mathrm{B}} \exp \left[w_{\mathrm{CaCl}_{2}}\left(a_{1 \mathrm{CaCl}_{2}}+a_{2 \mathrm{CaCl}_{2}} 10^{-4} t-a_{3 \mathrm{CaCl}_{2}} 10^{-6} t^{2}\right)+\right. \\
& \left.+w_{\mathrm{MgCl}_{2}}\left(a_{1 \mathrm{MgCl}_{2}}+a_{2 \mathrm{MgCl}_{2}} 10^{-4} t-a_{3 \mathrm{MgCl}_{2}} 10^{-6} t^{2}\right)\right], \\
\mu= & \mu_{8} \exp \left[w_{\mathrm{CaCl}_{2}}\left(b_{1 \mathrm{CaCl}_{2}}+b_{2 \mathrm{CaCl}_{2}} 10^{-4} t-b_{3 \mathrm{CaCl}_{2}} 10^{-6} t^{2}\right)+\right. \\
& \left.+w_{\mathrm{MgCl}_{2}}\left(b_{1 \mathrm{MgCl}_{2}}+b_{2 \mathrm{MgCl}_{2}} 10^{-4} t-b_{3 \mathrm{MgCl}_{2}} 10^{-6} t^{2}\right)\right]
\end{aligned}
$$

The dependences of viscosity and density of the solutions on the temperature are shown in Fig. 3.

For stimulation of waterless oil or gas wells, the influence of the released bound water on the saline solution mix properties can be neglected due to its small volume. However, for stimulation of high water cut or injection wells, the influence of the formation or injected water can matter.

As a rule, the prevailing salt dissolved in the formation water is sodium chloride $(\mathrm{NaCl})$. The concentration of sodium chloride in the formation water can vary in a broad range. The results of studying the physical properties of this solution depending on the salt content, pressure and temperature are provided in papers [23, 29, 32-35].

If besides $\mathrm{NaCl}$, some small quantities of other salt types are found in the formation water, a 
nomogram for calculating the equivalent $\mathrm{NaCl}$ content based on the present salt type and content. To take the $\mathrm{NaCl}$ content influence on the properties of the produced solutions into account, the additivity principle described above can be used.

An example of dependencies of the viscosity and density of the sodium chloride solution on the pressure and temperature, the calculation of the correlations proposed in [29] for the weight concentration of $18 \%$ typical for the Badra oilfield (Iraq) is carried out. The results are provided in Fig. 3.

Under standard conditions, carbon dioxide $\left(\mathbf{C O}_{2}\right)$ is a gas with the density of $1.839 \mathrm{~kg} / \mathrm{m}^{3}$ and the viscosity of $0.0147 \mathrm{mPa} \cdot \mathrm{sec}$. The phase state of $\mathrm{CO}_{2}$ depending on the pressure and temperature is illustrated in Fig. 4.

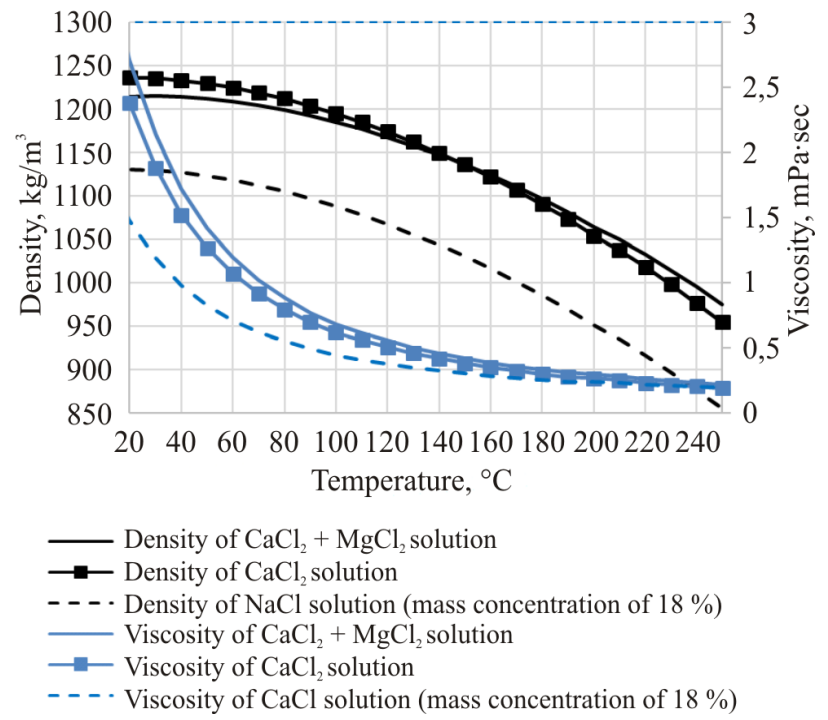

Fig. 3. Dependence of viscosity and density on the temperature for $\mathrm{CaCl}_{2}, \mathrm{CaCl}_{2}+\mathrm{MgCl}_{2}$ and $\mathrm{NaCl}$ solution

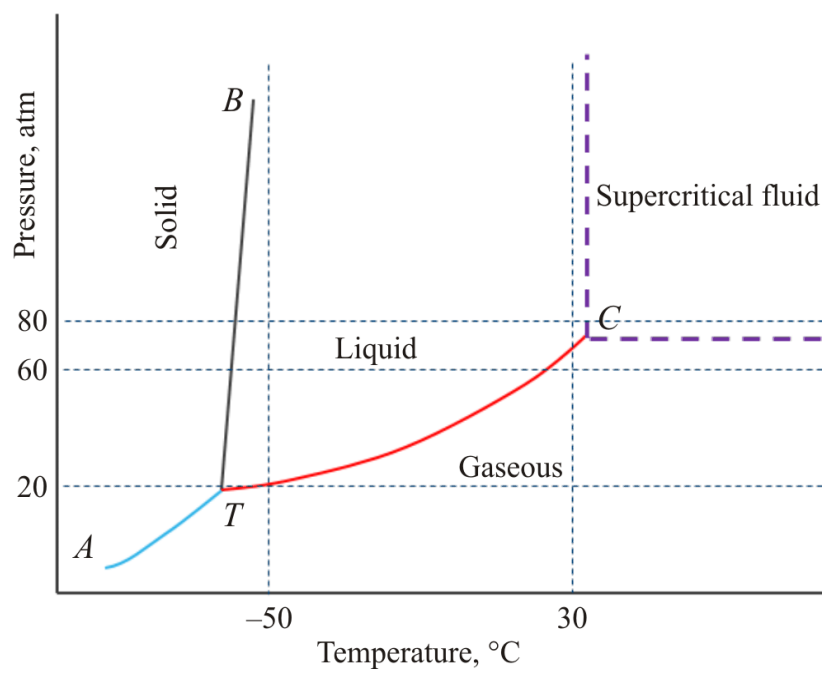

Fig. 4. $\mathrm{CO}_{2}$ phase state diagram
Carbon dioxide has critical parameters (point $C$ ): $T_{\text {cr }}=31^{\circ} \mathrm{C}$ and $P_{\mathrm{cr}}=72.9 \mathrm{~atm}[19]$.

The diagram shows that for the majority of cases of the considered range of pressure and temperature values, $\mathrm{CO}_{2}$ produced in the reaction under the formation conditions is in the supercritical fluid state and only in the pressure range from 3 to $7.3 \mathrm{MPa}$ it transitions into the gaseous phase. The properties of the substance in the supercritical fluid state are intermediate between those of the gaseous and fluid phases. The supercritical fluid is characterized by high density similar to liquid and low viscosity similar to gas.

\section{$\mathrm{CO}_{2}$ solubility}

Carbon dioxide is a gas rapidly soluble in water. The results of the laboratory measurements in $\mathrm{cm}^{3}{ }^{\circ} \mathrm{C}$ and $1 \mathrm{~atm}$ per $1 \mathrm{~g}$ of water (corresponding to $\mathrm{m}^{3} /$ tons) are provided in papers [36, 37].

The dependence of the carbon dioxide solubility in water on pressure and temperature was assessed by combining two studies (carried out for the temperatures below $100^{\circ} \mathrm{C}$ and above $200^{\circ} \mathrm{C}$ ) and is provided in Fig. 5.

The results of the study showed (see Fig. 5) that the solubility grows as the pressure increases. At lower pressures and temperatures, the solubility declines if the temperature begins to grow; after the pressure and temperature have gone up, however, the solubility also increases. This is explained by the fact that carbon dioxide reacts with water produced in carbon dioxide in water both in the ionic form and as a solution [38].

At the minimal values of the considered interval, the solubility will count around $15 \mathrm{~m}^{3} /$ ton; at maximum values, it reaches about $160 \mathrm{~m}^{3} /$ ton (by extrapolation).

The impact of the dissolved carbon dioxide on the water properties is studied in [38]. Based on the performed laboratory experiments, the following conclusions on the impact of the dissolved carbon dioxide on the water properties were made:

- water density depends on the concentration of the dissolved $\mathrm{CO}_{2}$ to a small extent, it can be therefore deemed independent of the $\mathrm{CO}_{2}$ concentration.

- water viscosity increases insignificantly with the growth of the dissolved $\mathrm{CO}_{2}$ concentration.

Whereas the volume of carbon dioxide involved in the reactions reaches about $55 \mathrm{~m}^{3} /$ ton of water, the presence of salts in the water reduces its solubility, and in certain cases, a part of gas remains undissolved. 


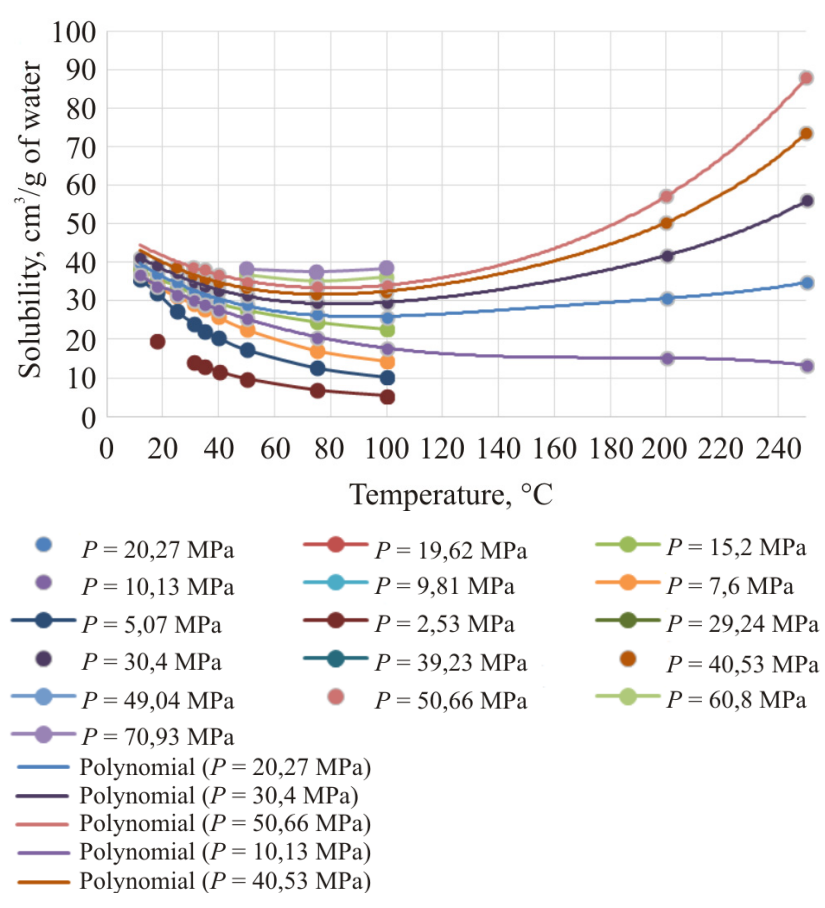

Fig. 5. Dependence of $\mathrm{CO}_{2}$ solubility on pressure and temperature
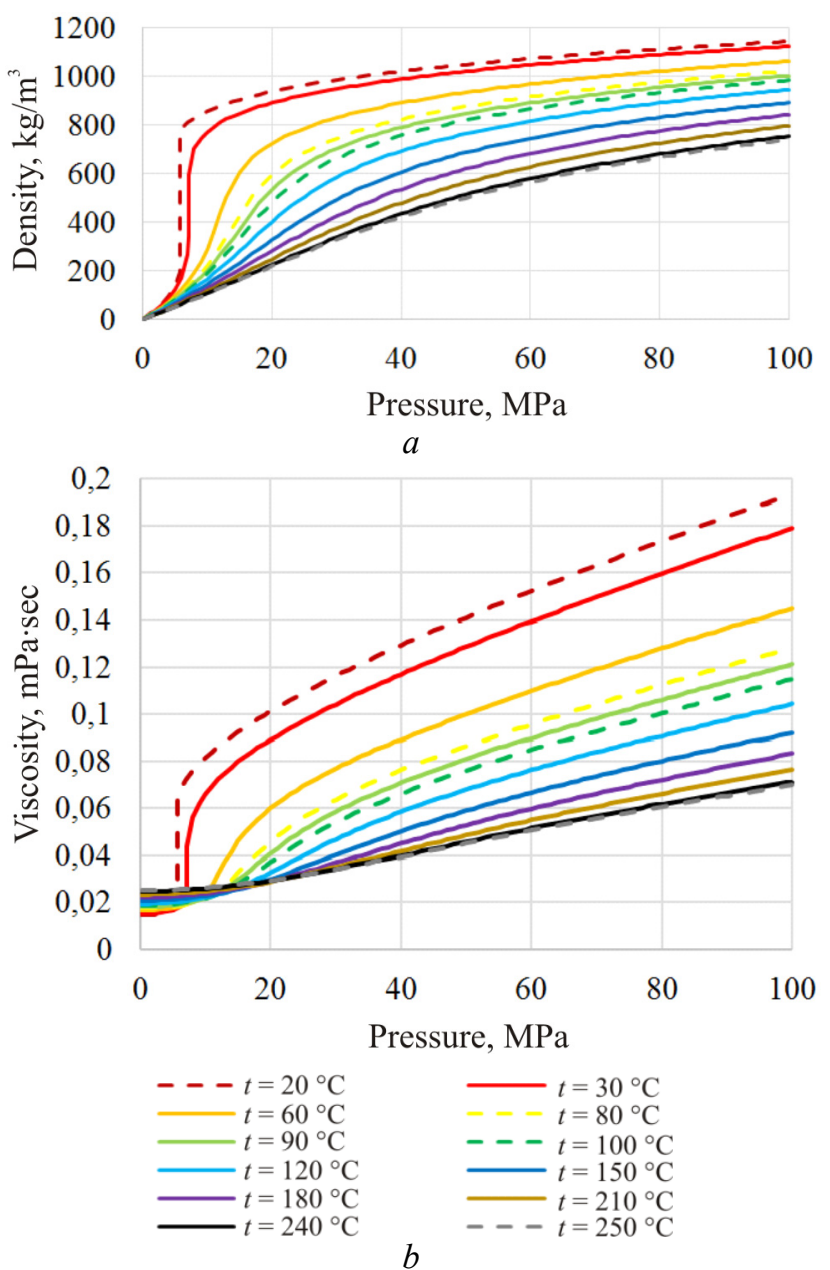

Fig. 6. Dependence of density $(a)$ and viscosity $(b)$ of $\mathrm{CO}_{2}$ on pressure and temperature

\section{$\mathrm{CO}_{2}$ density}

Gas density in a broad range of pressures and temperatures can be evaluated with the formulas proposed in [39].

The results of $\mathrm{CO}_{2}$ density calculations for the considered range of pressures and temperatures are provided in Fig. 6, $a$.

The volume factor calculated using density value is in the range from 0.029 to 0.0025 for the considered interval; therefore, the volume of carbon dioxide released in the reaction of $1 \mathrm{~m}^{3}$ of $15 \%$ acid ranges from 1.5 to $0.13 \mathrm{~m}^{3}$. Considering that from 30 to $100 \%$ of gas is dissolved in water, the volume occupied by the remaining $\mathrm{CO}_{2}$ will not exceed 1.05 $\mathrm{m}^{3}$. It is also necessary to keep in mind the good solubility of $\mathrm{CO}_{2}$ in oil, as that means that the free volume will be even less.

\section{$\mathrm{CO}_{2}$ viscosity}

The viscosity of gases increases with the growth of temperature and pressure. To calculate the ideal gas viscosity, Sutherland's formula can be used. However, this formula only considers the influence of temperature on the viscosity of gas.

Information about the viscosity of carbon dioxide in a broad range of pressures (up to $300 \mathrm{MPa}$ ) and temperatures (up to $726^{\circ} \mathrm{C}$ ) is provided in paper [40].

For the considered range of pressures and temperatures, the dependence of viscosity on pressure and temperature is shown in Fig. 6, $b$.

For the extreme values of the considered pressures and temperatures $\left(P_{\min }=3 \mathrm{MPa}, T_{\min }=30^{\circ} \mathrm{C}\right.$, $\left.P_{\max }=100 \mathrm{MPa}, T_{\min }=250{ }^{\circ} \mathrm{C}\right)$, the viscosity will amount to 0.017 and $0.07 \mathrm{mPa} \cdot \mathrm{sec}$.

The results of studying the properties of the gas and water mixture as a supercritical fluid have not been presented in any literature. However, for the practical purposes, the additivity principle can be assumed to apply to density calculation, and the apparent dynamic viscosity shall be deemed equal to that of the external environment (in our case, to the saline solution viscosity) [23]. Moreover, its impact on the properties of the saline solutions can be neglected due to the small resulting volume.

\section{Nitrogen (N)}

The phase diagram for $N$ is provided in paper [41] (Fig. 7). 


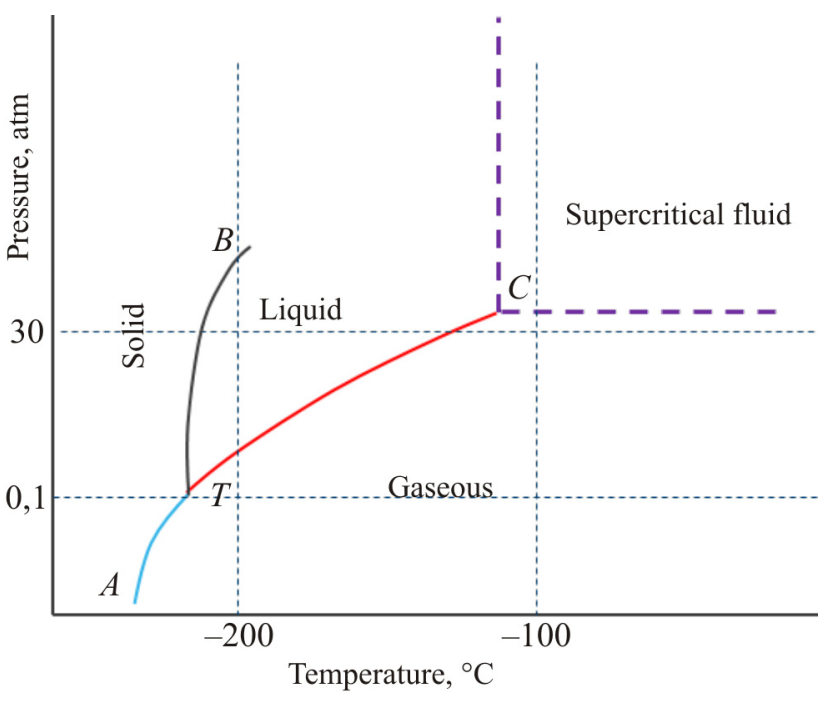

Fig. 7. Nitrogen phase state diagram
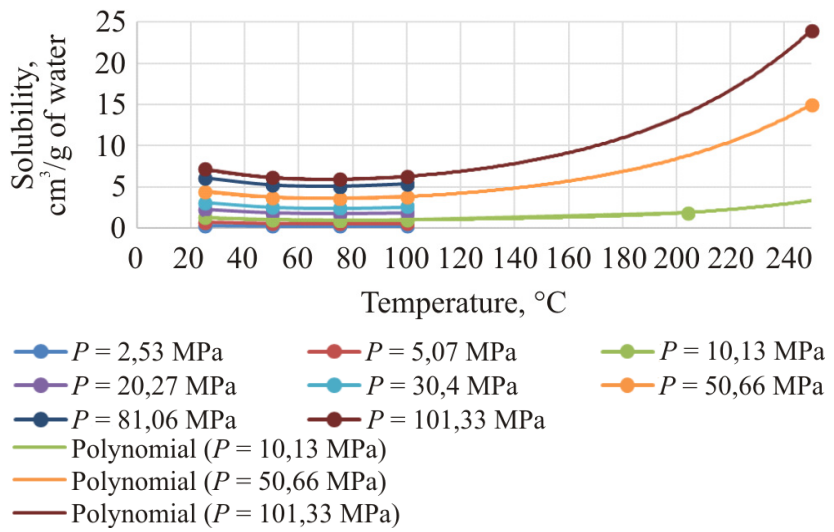

Fig. 8. Dependence of N solubility on pressure and temperature

The nitrogen has the following critical parameters: $T_{\text {cr }}=-146.94^{\circ} \mathrm{C}$ and $P_{\text {cr }}=33.9 \mathrm{~atm}$ [29]. It is a colourless gas with the density of $1.25 \mathrm{~kg} / \mathrm{m}^{3}$ in normal conditions, $1.16 \mathrm{~kg} / \mathrm{m}^{3}$ in standard conditions and viscosity of $0.01665 \mathrm{mPa} \cdot \mathrm{sec}$ in normal conditions and $0.01766 \mathrm{mPa} \cdot \mathrm{sec}$ in standard conditions [42].

In Fig. 7, we see that in the majority of cases within the considered range of pressure and temperature values, the nitrogen used for acid treatment is in the state of supercritical fluid and only at the pressure values below $33.9 \mathrm{~atm}$ it transitions to the gaseous state.

The solubility of nitrogen in water is significantly lower than that of carbon dioxide. The laboratory measurement results are provided in $[36,37,43,44]$. Combined research results were presented as a graph in Fig. 8.

In the graph we can see that the solubility of nitrogen at the maximum considered pressures and temperatures does not exceed $24 \mathrm{~m}^{3} /$ ton, and the minimum solubility value is $0.5 \mathrm{~m}^{3} /$ ton.
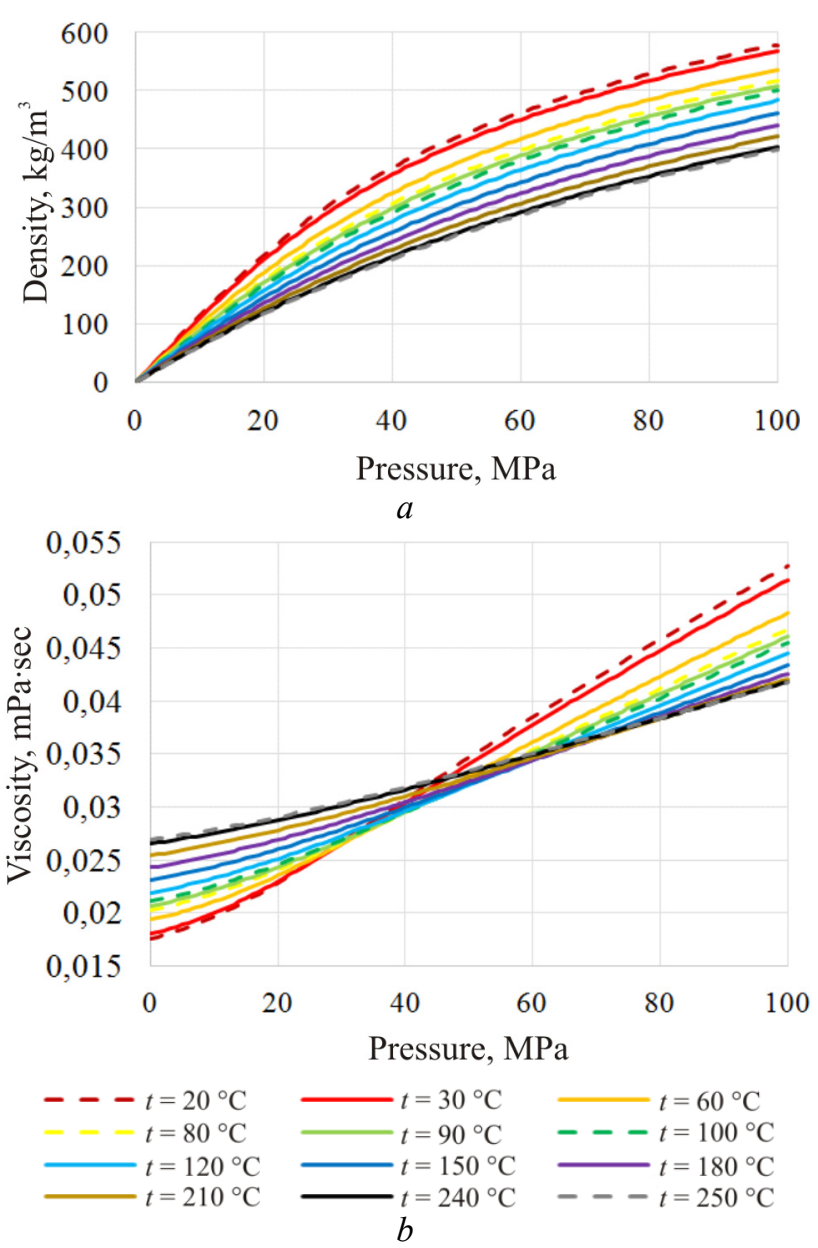

Fig. 9. Dependence of density $(a)$ and viscosity $(b)$ of nitrogen on pressure and temperature

\section{$\mathbf{N}_{2}$ density and viscosity}

The density and viscosity of gas for the considered pressures and temperatures were evaluated according to the formulas proposed in $[45,46]$.

The estimated values of density and viscosity for the considered range of pressures and temperatures are provided in Fig. 9, $a, b$.

The nitrogen density for the extreme values amounts to 1.16 and $399 \mathrm{~kg} / \mathrm{m}^{3}$, respectively, and viscosity amounts to 0.01766 and $0.042 \mathrm{mPa} \cdot \mathrm{sec}$.

\section{Influence of the used additives on the properties of acid solutions and time of reaction with the rock}

At the moment, for acid treatment compound acid compositions are usually selected, which includes additives to prevent or mitigate the negative impact of the acid on the well equipment and near wellbore area (corrosion inhibitors, demulsifiers, reagents preventing clay swelling etc.) and to 
improve of efficiency of the intervention process (reagents, reduced friction, diverters, reaction inhibitors, etc.).

Some of the additives used in certain concentrations may materially change the properties of the injected fluids and products of their reaction with the rock both constantly and within a definite time interval. Therefore, it is necessary to assess the extent of the impact these additives make on the physical properties of the used solutions and reaction products within the range of the pressures and temperatures expected from the acid treatment.

Due to the wide range of additives available and a broad range of possible pressures and temperatures, the most reliable source of information is the laboratory and oilfield experiments carried out in the conditions similar to those expected during the acid treatment. The academic literature provides a significant number of papers devoted to the impact of different additives on the acid treatment efficiency [47-51].

For primary well treatment in the Badra oilfield, the following compositions were tested and used:

- acid solution: $15 \% \mathrm{HCl}+1 \%$ iron stabilizer + $2.5 \%$ corrosion inhibitor $+2 \%$ demulsifier $+0.5 \%$ clay stabilizer;

- solution with diverter agent of chemical type: $15 \% \mathrm{HCl}+1 \%$ iron stabilizer $+2.5 \%$ corrosion inhibitor $+2 \%$ demulsifier $+0.5 \%$ clay stabilizer + $4.5 \%$ diverter (ZPWD-10).

The acid was used as the main treatment agent because the productive formation was represented by the limestone of cavernous and porous type with the calcite content of $85-95 \%$.

Laboratory tests have shown that the impact of iron stabilizer, corrosion inhibitor, demulsifier and clay stabilizer on the physical properties of the solutions is not significant. The main impact was rendered by the diverter, which increased the viscosity of the acid solution in its initial state and during the reaction with the rock.

In its initial state, ZPWD-10 diverter is a pale yellow highly viscous liquid with the density of $1050 \mathrm{~kg} / \mathrm{m}^{3}$, supplied in 200-litre barrels.

In order to determine the influence of the diverter on the properties of the acid solution, the following three laboratory experiments have been performed:

1. Determination of the solution properties under different temperatures.

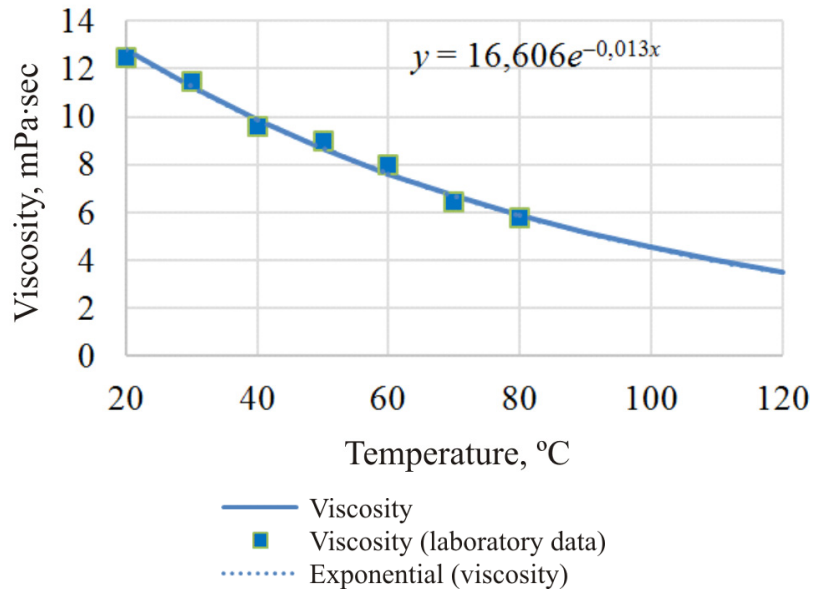

Fig. 10. Dependence of the change in viscosity on the temperature for the acid solution with diverter

This test was performed to evaluate the viscosity changes during the injection process.

Experiment methodology: the prepared solution $(300 \mathrm{ml})$ was heated to the required temperature and its viscosity was measured. The temperature ranged from 20 to $80^{\circ} \mathrm{C}$ with an interval of $20^{\circ} \mathrm{C}$.

The test results are provided in Fig. 10.

The evaluation of the acid solution density with diverter has shown the values close to the parameters of a $15 \%$ acid solution.

2. Determination of the solution properties during reaction with the rock.

The purpose of the test is to determine the viscosity of the acid solution with diverter in the process of its reaction with the rock.

Experiment methodology: the prepared solution $(500 \mathrm{ml})$ was heated to $80{ }^{\circ} \mathrm{C}$ in the water bath. Then $10 \mathrm{ml}$ portions of calcium carbonate were added and after the reaction, viscosity and acid concentration measurements were made. Then, calculations for the temperature of $120{ }^{\circ} \mathrm{C}$ were performed. The experiment results are shown in Fig. 11.

As we can see in Fig. 11, prior to the neutralization of about $30 \%$ of the acid composition (with the acid concentration of 10-11\%), the viscosity of the composition has hardly changed. With further reaction, the viscosity of the composition grows abruptly and reaches the maximum at the neutralization of $45 \%$ (with the acid concentration of $8.2 \%$ ) of the acid composition. In the further reaction process, the solution viscosity reduces and approximates to the viscosity of water. Thus, at the frontline of the acid composition movement with a diverter, a "narrow ring" of increased viscosity develops, diverting further portions of acid from the formed channels. 


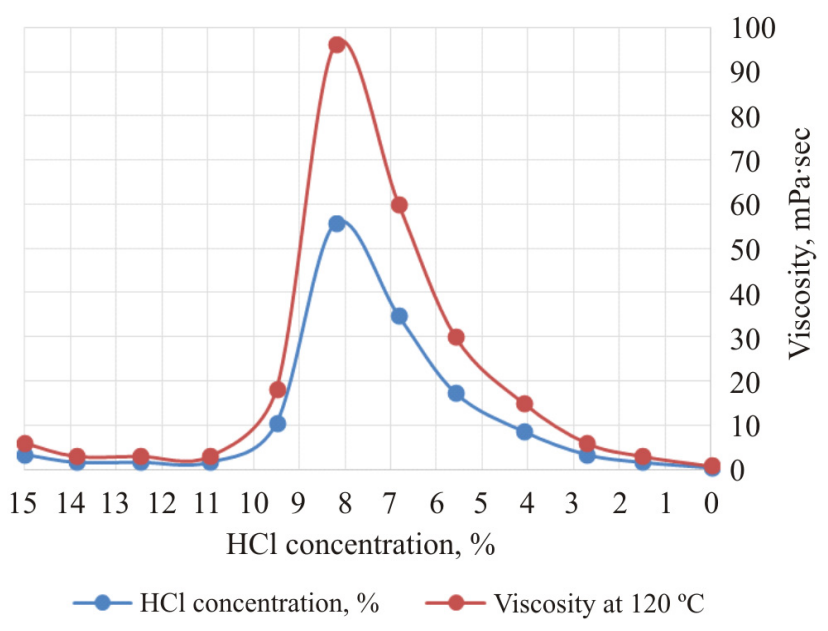

Fig. 11. Dependence of viscosity on $\mathrm{HCl}$ concentration in the acid solution neutralization process with a diverter at 120 and $80^{\circ} \mathrm{C}$
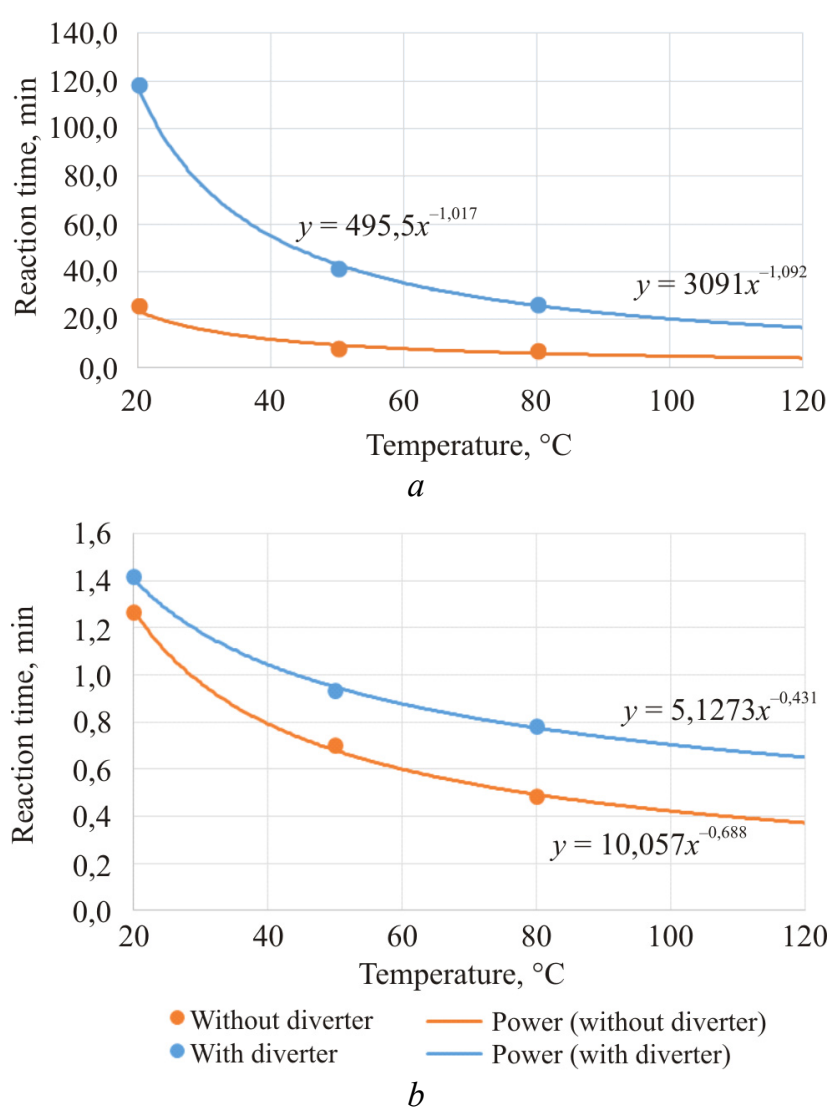

Fig. 12. The results of the experiment on the evaluation of reaction time of acid solutions without mixing $(a)$ and with constant mixing $(b)$

3. Determination of the neutralization time of the $15 \%$ acid solution with a diverter.

The purpose of the test is to determine the acid reaction time the with and without a diverter in case of excessive calcium carbonate content.

Experiment methodology: the prepared solution of the $15 \%$ acid composition without and with a diverter and a portion of $\mathrm{CaCO}_{3}$ were heated to a certain temperature in the water bath. The solution was added to calcium carbonate. The end of the reaction was evaluated visually as the termination of the carbon dioxide emission. The reaction time was measured with a timer. The experiments were performed at the atmospheric pressure and the temperatures of 20,50 and $80{ }^{\circ} \mathrm{C}$ with constant mixing (continuous feeding of new portions of acid to the rock, simulating injection of acid under pressure) and without it (acid bath simulation). The experiment results are shown in Fig. 12, $a, b$.

The experiment results show that the presence of a diverter in the solution slows down the speed of reaction with calcium carbonate.

Constant feeding of the new portions of acid solutions to the reaction surface significantly increases the speed of reaction of the solutions both with and without a diverter.

The growth of temperature and the reaction surface area materially increases the reaction speed.

The time of reaction at a temperature over $80{ }^{\circ} \mathrm{C}$ (typical of the Badra oilfield) and with constant feeding of the new portions of acid compositions to the reaction surface (mixing effect) does not exceed $1 \mathrm{~min}$ for the solution with a diverter and $30 \mathrm{sec}$ for the solution without a diverter, i.e. the reaction on the mineral surface is practically instant. The impact of the pressure on the reaction time for the Badra oilfield was not assessed.

Thus, the total reaction time for acid treatment conditions (injection under pressure) at the Badra oilfield $\left(T=80-120{ }^{\circ} \mathrm{C}, P=35-51 \mathrm{MPa}\right)$ depends on the speed of the acid delivery to the surface as a slower process, and the reaction speed at the surface of the mineral can be neglected (considered instant) [5] both for the acid solution with and without the diverter.

\section{Conclusion}

The performed analysis showed that in the range of pressures and temperatures arising in the process of acid treatment:

- $\mathrm{MgCl}_{2}$ and $\mathrm{CaCl}_{2}$ salts produced in the reaction of $15 \% \mathrm{HCl}$ with carbonates are in the dissolved state;

- the main impact on the pressure and viscosity of these solutions is rendered by the change of temperature. The influence of changes in the pressure 
and volume of the dissolved gas on these parameters may be neglected for practical calculations;

- carbon dioxide is highly soluble in water and oil. If the $\mathrm{CO}_{2}$ volume is not fully dissolved in water or oil, within the considered range it will be in the state of a supercritical fluid with the properties depending on both pressure and temperature.

- the use of additives in the acid solutions may have a material impact on their properties;

- the ZPWD-10 additive used as a diverter for acid treatment at the Badra oilfield significantly increases the viscosity of acid solution allowing to create a short-term "narrow band" of a highly viscous fluid in the frontline of the acid movement, diverting the flows to the unprocessed formation areas.

The dependences provided in the paper were used in the process of acid treatment planning for the wells of the Badra oilfield.

\section{References}

1. Glushchenko V.N., Silin M.A. Neftepromyslovaia khimiia. Vol. 4. Kislotnaia obrabotka skvazhin [Oilfield chemistry. Vol. 4. Wells acid treatment]. Moscow, Interkontakt nauka, 2010, 703 p.

2. Surguchev M.L., Kolganov V.I., Gavura A.V. Izvlechenie nefti iz karbonatnykh kollektorov [Oil recovery from carbonate reservoirs]. Moscow, Nedra, 1987, 230 p.

3. Davydov A.B., Chernitskii A.B. Razrabotka mestorozhdenii $\mathrm{s}$ karbonatnymi kollektorami: tekushchee sostoianie, problemy, perspektivy [Development of deposits with carbonate reservoirs: current status, problems and prospects]. Oil industry, 1993, no. 3, pp. 18-21.

4. Kingston V.M., Morris M.V. Khimicheskaia obrabotka skvazhin [Chemical treatment of wells]. BAKU-M: OMTI MRTP-FzONTI, 1938, 80 p.

5. Economides M.J., Nolte K.G. Reservoir stimulation. New York, JohnWilley\& Sons, LTD, 2000, 815 p.

6. Bochkov I.V. Obrabotka neftianykh skvazhin na verkhne-chusovskom neftepromysle imeni Stalina [Treatment of oil wells in the Upper Chusovoy oilfield named after Stalin]. ANKh, 1938, no. 2, pp. 25-31.

7. Maksimov M.I. Obrabotka skvazhin solianoi kislotoi [Treatment of wells with hydrochloric acid]. Moscow-Leningrad: Gostoptekhizdat, 1945, $163 \mathrm{p}$.
8. Gazizov A.A. Uvelichenie nefteotdachi neodnorodnykh plastov na pozdnei stadii razrabotki [Increased oil recovery in heterogeneous formations at a late stage of development]. Moscow, NedraBiznestsentr, 2002, $639 \mathrm{p}$

9. Suchkov B.M. Dobycha nefti iz karbonatnykh kollektorov [Oil production from carbonate reservoirs]. Izhevsk, NITs RKhD, 2005, 688 p.

10. Muslimov R.Kh. Sovremennye metody povysheniia nefteizvlecheniia: proektirovanie, optimizatsiia i otsenka effektivnosti [Modern methods of increasing oil recovery: design, optimization and performance evaluation]. Kazan, FEN AN RT, 2005, 688 p.

11. Smirnov A.S. Matematicheskoe modelirovanie protsessa zakachki kisloty $\mathrm{v}$ karbonatnyi plast s uchetom formirovaniia "chervotochin" [Mathematical modeling of the acid injection process into the carbonate formation, taking into account the formation of "wormholes"]. Abstract of Ph. D. thesis. Tiumen, TGU, 2011, 26 p.

12. Volnov I.A. Modelirovanie kislotnogo vozdeistviia na karbonatnye neftesoderzhashchie plasty [Modeling the acid treatment on carbonate oilbearing formations]. Abstract of $\mathrm{Ph}$. D. thesis. Moscow, 2009, 124 p.

13. Zhuchkov S.Iu. Modelirovanie kislotnogo vozdeistviia na prizaboinuiu zonu gorizontalnoi skvazhiny [Modeling the acid treatment on the bottomhole zone of a horizontal well]. Ph. D. thesis. Moscow, 2013. 100 p.

14. Sharifullin A.R. Matematicheskoe modelirovanie kislotnykh obrabotok skvazhin $\mathrm{V}$ sloisto-neodnorodnykh karbonatnykh kollektorakh [Mathematical modeling acid treatments of wells in layered heterogeneous carbonate reservoirs]. $\mathrm{Ph}$. D. thesis. Ufa, 2010, $139 \mathrm{p}$.

15. Kanevskaia R.D., Novikov A.V. Metody modelirovaniia chervotochin pri soliano-kislotnom vozdeistvii na karbonatnye plasty [Methods of wormholes simulation under hydrochloric acid impact on carbonate formations]. Oilfield engineering, 2018, no. 3, pp. 19-28. DOI: 10.30713/0207-2351-2018-3-19-28

16. Fredd C.N. Validation of carbonate matrix stimulation models. International Symposium on Formation Damage Control held in Lafayette. Louisiana, 2000, SPE 58713, available at: www.onepetro.org (accessed 12 September 2019). DOI: $10.2118 / 58713-\mathrm{MS}$

17. Kirkinskaia V.N., Smekhov E.M. Karbonatnye porody-kollektory nefti i gaza [Carbonate oil 
and gas reservoir rocks]. Leningrad, Nedra, $1981,255 \mathrm{p}$.

18. Schechter R.S. Oil well stimulation. Prentice Hall, New Jersey, 1992, 602 p.

19. Nikolskii B.P., Grigorov O.N., Pozin M.E. Spravochnik khimika [Chemist's handbook]. Moscow, Khimiia, 1966.

20. Mikheev M.A., Mikheeva I.M. Osnovy teploperedachi [Heat transfer basics]. Moscow, Energija, 1977, 344 p.

21. Krichlou G.B. Sovremennaia razrabotka neftianykh mestorozhdenii - problemy modelirovaniia [Modern oilfield development - modeling issues]. Moscow, Nedra, 1979, 303 p.

22. Aziz Kh., Settari E. Matematicheskoe modelirovanie plastovykh sistem [Mathematical modeling of reservoir systems]. Moscow, Nedra, 1982, $407 \mathrm{p}$.

23. Mishchenko I.T., Sakharov V.A. Sbornik zadach po tekhnologii i tekhnike neftedobychi [Collection of tasks on technology and technology of oil production]. Moscow, Nedra, 1984, $272 \mathrm{p}$.

24. Perri D.G. Spravochnik inzhenera-khimika [Chemical engineer's handbook]. Leningrad, Khimiia, 1969.

25. Nishikata E., Ishii T., Ohta T. Viscosities of aqueous hydrochloric acid solutions, and densities and viscosities of aqueous hydroiodic acid solutions. J. Chem. Eng. Data, 1981, 26, pp. 254-256. DOI: $10.1021 / \mathrm{je} 00025 \mathrm{a} 008$

26. Rabinovich V.A., Khavin Z.Ia. Kratkii khimicheskii spravochnik [Brief chemical handbook]. Leningrad, Khimiia, 1978, 281 p.

27. Lazarev A.I., Kharlamov I.P., Iakovlev P.Ia., Iakovleva E.F. Spravochnik khimika-analitika [Chemist-analyst's handbook]. Moscow, Nedra, 1976, $184 \mathrm{p}$.

28. Komarov N.S. Spravochnik kholodilshchika [Refrigerationist's handbook]. Moscow, Mashgiz, 1962, $419 \mathrm{p}$.

29. Bobylev V.N. Fizicheskie svoistva naibolee izvestnykh khimicheskikh veshchestv [Physical properties of the best known chemicals]. Moscow, RKhTU im. D.I. Mendeleeva, 2003, 24 p.

30. Collins A.G. Properties of produced waters (1987 PEH Chapter 24). SPE, 1987, SPE-1987-24PEH, available at: www.onepetro.org (accessed 12 September 2019).

31. Grosheva L.P. Raschetnoe opredelenie nekotorykh svoistv solei [Calculation of some properties of salts]. Novgorod, Novgorodskii gosudarstvennyi universitet, 2006, $21 \mathrm{p}$.

32. Tarek A. Reservoir engineering handbook. Gulf Professional Publishing, 2010, 866 p.

33. Matthews C., Russell D. Pressure buildup and flow tests in wells. SPE New York, 1967, 167 p.

34. Meehan D. A Correlation for water compressibility. Petroleum Engineer, 1980, November, pp. 125-126.

35. Brill J., Beggs H. Two-phase flow in pipes. Tulsa, The University of Tulsa, 1978. $638 \mathrm{p}$.

36. Namiot A.Iu. Rastvorimost gazov v vode pod davleniem [The solubility of gases in water under pressure]. Moscow, Gostoptekhizdat, 1963, $148 \mathrm{p}$.

37. Namiot A.Iu. Rastvorimost gazov $\mathrm{v}$ vode [The solubility of gases in water]. Moscow, Nedra, 1991, $167 \mathrm{p}$.

38. Balint V., Ban A., Doleshal Sh. primenenie uglekislogo gaza $\mathrm{v}$ dobyche nefti [Application of carbon dioxide in oil production]. Moscow, Nedra, 1977, 240 p.

39. Span R., Wagner W. A new equation of state for carbon dioxide covering the fluid region from the triple-point temperature to $1100 \mathrm{~K}$ at pressures up to $800 \mathrm{MPa}$. J. Chem. Eng. Data, 1996, 25, pp. 1509-1596. DOI: $10.1063 / 1.555991$

40. Wakeham W.A. The viscosity of carbon dioxide. Journal of Physical and Chemical Reference Data, 1998, vol 27, no. 1, pp. 31-44.

41. Fracz W., Janowski G., Ryzinska G. Selected aspects of manufacturing and strength evaluation of porous composites based on numerical simulations. Zeszyty Naukowe Politechniki Rzeszowskiej 295, Mechanika 89, RUTMech, 2017, vol. XXXIV, z. 89 (1/17), s. 31-43.

42. Tablitsy fizicheskikh velichin [Tables of physical quantities]. Ed. I.k. Kikoina. Moscow, Atomizdat, 1976, $1008 \mathrm{p}$.

43. Gilespie P.C., Wilson G.M. Vapor-liquid equilibrium data on water-substitute gas components, Research Report 41. Gas Processors Association, 1980, 68 p.

44. Japas M.L., Frank E.U. High pressure phase equilibria and PVT - data of the water nitrogen system to $673 \mathrm{~K}$ and $250 \mathrm{MPa}$. Ber. Bunsenges. Phys. Chem., 1985, B.89, s. 793-800. DOI: $10.1002 / b b p c .19850890714$

45. Span R., Lemmon E.W., Jacobsen R.T., Wagner W., Yokozeki A. A reference equation 
of state for the thermodynamic properties of nitrogen for temperatures from 63.151 to $1000 \mathrm{~K}$ and pressures to $2200 \mathrm{MPa}$. J. Phys. Chem. Ref. Data, 2000, 29, 6, pp.1361-1433. DOI: $10.1063 / 1.1349047$

46. Jacobsen R.T., Stewart R.B., Jahangiri M. Thermodynamic properties of nitrogen from the freezing line to $2000 \mathrm{~K}$ at pressures to $1000 \mathrm{MPa}$. J. Phys. Chem. Ref. Data, 1986, 15(2), pp. 735-909. DOI: 10.1063/1.555754

47. Khizhniak G.P., Amirov A.M., Gladkikh E.A., Kozlov A.A., Kolesov V.A., Zakharian A.G., Pestrikov A.V., Chikin A.E., Komin M.A., Harris R. Laboratory tests of DEEPA acid-generating compound. Perm Journal of Petroleum and Mining Engineering, 2015, no. 14, pp. 18-31. DOI: 10.15593/2224-9923/2015.14.3

48. Iliushin P.Iu., Rakhimzianov R.M., Solov'ev D.Iu., Kolychev I.Iu. Analysis of well intervention aimed at oil production enhancement in the Perm krai's fields. Perm Journal of Petroleum and Mining Engineering, 2015, no. 15, pp. 81-89. DOI: $10.15593 / 2224-9923 / 2015.15 .9$

49. Glushchenko V.N., Ptashko O.A. Filtratrion research of novel acidic compounds for treatment of carbonate reservoirs. Perm Journal of Petroleum and Mining Engineering, 2014, no. 11, pp. 46-56. DOI: $10.15593 / 2224-9923 / 2014.11 .5$

50. Poplygin V.V., Davydova I.S., Kuznetsov I.V., Galkin S.V. Composition DN-9010 Treatments results on bottomhole zones of the layer BSH oilfields of VKMKS area. Perm Journal of Petroleum and Mining Engineering, 2010, no. 5, pp. 70-74.

51. Pavlovskaia E., Poplygin V.V., Ivanov D.Iu., Eliseev I.Iu. Effektivnost kislotnykh obrabotok skvazhin, ekspluatiruiushchikh bashkirskie otlozheniia na mestorozhdeniiakh permskogo kraia [Effectiveness of acidizing in Bashkir deposits of Perm Region]. Oil industry, 2015, no. 3 , pp. 28-31.

\section{Библиографический список}

1. Глущенко В.Н., Силин М.А. Нефтепромысловая химия: в 5 т. Т. 4. Кислотная обработка скважин.- М.: Интерконтакт Наука, 2010. $703 \mathrm{c}$.

2. Сургучев М.Л., Колганов В.И., Гавура А.В. Извлечение нефти из карбонатных коллекторов. М.: Недра, 1987. - 230 с.
3. Давыдов А.В., Черницкий А.В. Разработка месторождений с карбонатными коллекторами: Текущее состояние, проблемы, перспективы // Нефтяное хозяйство. - 1993. - № 3. C. $18-21$.

4. Кингстон В.М., Моррис М.В. Химическая обработка скважин. - Баку-М: ОНТИ НКТПФзОНТИ, 1938. - 80 с.

5. Economides M.J., Nolte K.G. Reservoir stimulation. - New York: JohnWilley\& Sons, LTD, 2000. $-815 \mathrm{p}$.

6. Бочков И.В. Обработка нефтяных скважин на Верхне-Чусовском нефтепромысле имени Сталина // АНХ. - 1938. - № 2. - С. 25-31.

7. Максимов М.И. Обработка скважин соляной кислотой. - М.-Л.: Гостоптехиздат, 1945. $163 \mathrm{c}$.

8. Газизов А.А. Увеличение нефтеотдачи неоднородных пластов на поздней стадии разработки. - М.: Недра-Бизнесцентр, 2002. $639 \mathrm{c}$.

9. Сучков Б.М. Добыча нефти из карбонатных коллекторов. - Ижевск: НИЦ РХД, 2005. - 688 с.

10. Муслимов Р.X. Современные методы повышения нефтеизвлечения: проектирование, оптимизация и оценка эффективности: учеб. пособие. - Казань: ФЭН АН РТ, 2005. $688 \mathrm{c}$.

11. Смирнов А.С. Математическое моделирование процесса закачки кислоты в карбонатный пласт с учетом формирования «червоточин»: автореф. дис. ... канд. физ.-мат. наук. - Тюмень: ТГУ, 2011. $-26 \mathrm{c}$.

12. Вольнов И.А. Моделирование кислотного воздействия на карбонатные нефтесодержащие пласты: дис. ... канд. техн. наук. - М., 2009. $124 \mathrm{c}$.

13. Жучков С.Ю. Моделирование кислотного воздействия на призабойную зону горизонтальной скважины: диссертация ... канд. техн. наук. M., 2013. $-100 \mathrm{c}$.

14. Шарифуллин А.P. Математическое моделирование кислотных обработок скважин в слоисто-неоднородных карбонатных коллекторах: дис. ... канд. техн. наук. - Уфа, 2010. $139 \mathrm{c}$.

15. Каневская Р.Д., Новиков А.В. Методы моделирования червоточин при солянокислотном воздействии на карбонатные пласты // Нефтепромысловое дело. - 2018. - № 3. C. $19-28$. 
16. Fredd C.N. Validation of carbonate matrix stimulation models [Электронный pecypc] // International Symposium on Formation Damage Control held in Lafayette. - Louisiana, 2000. SPE 58713. - URL: www.onepetro.org. (дата обращения: 12.09.2019).

17. Киркинская В.Н., Смехов Е.М. Карбонатные породы-коллекторы нефти и газа. - Л.: Недра, 1981. -255 c.

18. Schechter R.S. Oil well stimulation. Prentice Hall, New Jersey, 1992. - 602 p.

19. Никольский Б.П., Григоров О.Н., Позин М.Е. Справочник химика. - М.: Химия, 1966.

20. Михеев М.А., Михеева И.М. Основы теплопередачи. - М.: Энергия, 1977. - 344 с.

21. Кричлоу Г.Б. Современная разработка нефтяных месторождений - проблемы моделирования. - М.: Недра, 1979. - 303 с.

22. Азиз Х., Сеттари Э. Математическое моделирование пластовых систем. - М.: Недра, 1982. - $407 \mathrm{c}$.

23. Мищенко И.Т., Сахаров В.А. Сборник задач по технологии и технике нефтедобычи. М.: Недра, 1984. - 272 с.

24. Перри Д.Г. Справочник инженера-химика. Л.: Химия, 1969.

25. Nishikata E., Ishii T., Ohta T. Viscosities of aqueous hydrochloric acid solutions, and densities and viscosities of aqueous hydroiodic acid solutions // J. Chem. Eng. Data. - 1981. - 26. - P. 254-256.

26. Рабинович В.А., Хавин 3.Я. Краткий химический справочник. - Л.: Химия, 1978. - 281 с.

27. Справочник химика-аналитика / А.И. Лазарев, И.П. Харламов, П.Я. Яковлев, Е.Ф. Яковлева. - М.: Металлургия, 1976. - 184 с.

28. Комаров Н.С. Справочник холодильщика. М.: Машгиз, 1962. - 419 с.

29. Бобылёв В.Н. Физические свойства наиболее известных химических веществ. М.: РХТУ им. Д.И. Менделеева, 2003. $24 \mathrm{c}$.

30. Collins A.G. Properties of produced waters (1987 PEH Chapter 24) [Электронный ресурс] // SPE. - 1987. - SPE-1987-24-PEH. - URL: www.onepetro.org. (дата обращения: 12.09.2019).

31. Грошева Л.П. Расчетное определение некоторых свойств солей: учеб. пособие. Н. Новгород: Новгородский государственный университет, 2006. - 21 с.

32. Tarek A. Reservoir engineering handbook. Gulf Professional Publishing, 2010. - 866 p.
33. Matthews C., Russell D. Pressure buildup and flow tests in wells. - New York, 1967. - $167 \mathrm{p}$.

34. Meehan D. A Correlation for water compressibility // Petroleum Engineer. - 1980. November. - P. 125-126.

35. Brill J., Beggs H. Two-phase flow in pipes. Tulsa: The University of Tulsa, 1978. 638 p.

36. Намиот А.Ю. Растворимость газов в воде под давлением. - М.: Гостоптехиздат, 1963. - 148 с.

37. Намиот А.Ю. Растворимость газов в воде: справ. пособие. - М.: Недра, 1991. - 167 с.

38. Балинт В., Бан А., Долешал Ш. Применение углекислого газа в добыче нефти. - М.: Недра, 1977. - 240 с.

39. Span R., Wagner W. A new equation of state for carbon dioxide covering the fluid region from the triple-point temperature to $1100 \mathrm{~K}$ at pressures up to $800 \mathrm{MPa} / /$ J. Chem. Eng. Data. - 1996. - 25. P. 1509-1596.

40. Wakeham W.A. The viscosity of carbon dioxide // Journal of Physical and Chemical Reference Data. - 1998. - Vol 27, № 1. P. 31-44.

41. Fracz W., Janowski G., Ryzinska G. Selected aspects of manufacturing and strength evaluation of porous composites based on numerical simulations // Zeszyty Naukowe Politechniki Rzeszowskiej 295, Mechanika 89, RUTMech. - 2017. - T. XXXIV, z. $89(1 / 17)$. - S. 31-43.

42. Таблицы физических величин: справ. / под ред. акад. И.К. Кикоина. - М.: Атомиздат, 1976. $-1008 \mathrm{c}$.

43. Gilespie P.C., Wilson G.M. Vapor - liquid equilibrium data on water-substitute gas components, Research Report 41. - Gas Processors Association, 1980.

44. Japas M.L., Frank E.U. High pressure phase equilibria and PVT - data of the water - nitrogen system to $673 \mathrm{~K}$ and $250 \mathrm{MPa} / /$ Ber. Bunsenges. Phys. Chem. - 1985. - B. 89. - P. 793-800.

45. A Reference equation of state for the thermodynamic properties of nitrogen for temperatures from 63.151 to $1000 \mathrm{~K}$ and pressures to $2200 \mathrm{MPa} / \mathrm{R}$. Span, E.W. Lemmon, R.T. Jacobsen, W. Wagner, A. Yokozeki // J. Phys. Chem. Ref. Data. - 2000. - 29 (6). - P. 1361-1433.

46. Jacobsen R.T., Stewart R.B., Jahangiri M. Thermodynamic properties of nitrogen from the freezing line to $2000 \mathrm{~K}$ at pressures to $1000 \mathrm{MPa} / /$ J. Phys. Chem. Ref. Data. - 1986. - 15(2). P. 735-909. 
47. Лабораторные испытания кислотогенерирующего состава DEEPA / Г.П. Хижняк, А.М. Амиров, Е.А. Гладких [и др.] // Вестник Пермского национального исследовательского политехнического университета. Геология. Нефтегазовое и горное дело. - 2015. - № 14. - С. 18-31.

48. Анализ проведения геолого-технических мероприятий по увеличению продуктивности добывающих скважин на нефтяных месторождениях Пермского края / П.Ю. Илюшин, Р.М. Рахимзянов, Д.Ю. Соловьев, И.Ю. Колычев // Вестник Пермского национального исследовательского политехнического университета. Геология. Нефтегазовое и горное дело. - 2015. - № 15. C. 81-89.

49. Глущенко В.Н., Пташко О.А. Фильтрационные исследования новых кислотных составов для обработки карбонатных коллекторов // Вестник Пермского национального исследовательского политехнического университета. Геология. Нефтегазовое и горное дело. - 2014. - № 11. - С. 46-56.

50. Результаты обработок составом ДН-9010 призабойных зон пластов Бш нефтяных месторождений района ВКМК / В.В. Поплыгин, И.С. Давыдова, И.В. Кузнецов, С.В. Галкин // Вестник Пермского национального исследовательского политехнического университета. Геология. Нефтегазовое и горное дело. - 2010. № 5. - C. 70-74.

51. Эффективность кислотных обработок скважин, эксплуатирующих башкирские отложения на месторождениях Пермского края / Е. Павловская, В.В. Поплыгин, Д.Ю. Иванов, И.Ю. Елисеев // Нефтяное хозяйство. - 2015. - № 3. - С. 28-31.

Please cite this article in English as:

Khuzin R.A., Yushchenko T.S., Khizhniak G.P. Changes in the properties of fluids and chemical reactions products caused by acid treatment of carbonate reservoirs. Perm Journal of Petroleum and Mining Engineering, 2019, vol.19, no.3, pp.275-289. DOI: $10.15593 / 2224-9923 / 2019.3 .7$

Просьба ссылаться на эту статью в русскоязычных источниках следующим образом:

Хузин Р.А., Ющенко Т.С., Хижняк Г.П. Изменение свойств флюидов и продуктов химических реакций при солянокислотных обработках карбонатных коллекторов // Вестник Пермского национального исследовательского политехнического университета. Геология. Нефтегазовое и горное дело. - 2019. - Т.19, №3. - С.275-289. DOI: $10.15593 / 2224-9923 / 2019.3 .7$ 